\title{
The influence of different combination of Nitrogen and Phosphorus on mungbean (Vigna radiata $\mathbf{L}$.
}

\author{
Anjum ${ }^{1}$, Muhammad Zahir Afridi ${ }^{1}$, Kashif Akhtar $^{2 *}$ and Vu Ngoc $\mathrm{Ha}^{3}$ \\ 1. Department of Agronomy, Amir Muhammad Khan Campus Mardan, The University of Agriculture Peshawar, \\ KPK, Pakistan. \\ 2. College of Agronomy, Northwest A \& F University, Yangling, Shaanxi, China \\ 3. College of Forestry, Northwest A \& F University, Yangling, Shaanxi, China \\ *Corresponding author's email: kashtoru@gmail.com
}

Citation

Anjum, Muhammad Zahir Afridi, Kashif Akhtar and Vu Ngoc Ha. The influence of different combination of Nitrogen and Phosphorus on mungbean (Vigna radiata L.). Pure and Applied Biology. Vol. 4, Issue 4, 2015, pp 605-610. http://dx.doi.org/10.19045/bspab.2015.44020

Received: $15 / 08 / 2015 \quad$ Revised: 09/11/2015

Accepted: $18 / 11 / 2015$

\section{Abstract}

Nitrogen and phosphorus are essential nutrients that effect mungbean (vigna radiata $\mathrm{L}$ ) growth and yield; therefore the experiment "influence of nitrogen and phosphorus on mungbean yield and yield components" in Palatoo Farm, AMKC Mardan was conducted during summer 2012 in a RCB design. The different combination of nitrogen and phosphorus (20-30, 40-60, 60-90 and $80-120 \mathrm{~kg} \mathrm{ha}^{-1}$ ) was applied to Mungbean cultivar NM-92. To observe the combine application of $\mathrm{N}+\mathrm{P}_{2} \mathrm{O}_{5}$ for the enhancing of yield and yield components of mungbean. Days to emergence were not affected. Days to flowering and maturity were decreased with $\mathrm{N}+\mathrm{P}_{2} \mathrm{O}_{5}$ combine application. Plant height, Pods plant ${ }^{-1}$, Seed pod $^{-1}$, 1000 grains weight, grain yield, biological yield and harvest index improved with $\mathrm{N}+\mathrm{P}_{2} \mathrm{O}_{5}$ increasing levels. The application of $60+40 \mathrm{~kg}$ $\mathrm{ha}^{-1}$ was superior in term of grain yield. Hence it can be concluded from this experiment that the combine application of $\mathrm{N}+\mathrm{P}_{2} \mathrm{O}_{5}$ at the rate of $60+40 \mathrm{~kg} \mathrm{ha}^{-1}$ was beneficial in agro-ecological condition of Mardan.

Keywords: Mungbean; $\mathrm{N}+\mathrm{P}_{2} \mathrm{O}_{5}$ combinations; Thousand grain weight; Yield; Wheat.

\section{Introduction}

Mungbean (Vigna radiata L.) commonly known as green gram is an important legume crop of Pakistan and other Asian countries. In Pakistan it occupied an area of 137 thousand hectare with total seed production of 77.1 thousand tones having an average yield of $562 \mathrm{~kg} \mathrm{ha}^{-1}$ [1]. It is mostly grown for human consumption where the diet is mostly cereal based [2]. It is a leguminous crop so it is potentially useful in improving cropping pattern and it can be grown as a catch crop due to its rapid growth and early maturing characteristic [3]. The average yield of mungbean is quite low. The one way to make improve the crop yield and production is the management of fertilizers that greatly affect the growth, development and yield of mungbean.

Nitrogen is very important nutrient among all essential nutrients [4]. Nitrogen is more useful because it is the main component of amino acid and protein. Adequate supply of nitrogen is very important for normal growth 
and yield of crops. Phosphorus is also an important nutrient to promote early root formation of lateral, fibrous and healthy roots, which are very important for nodule formation and N, fixation [4]. Application of Phosphorus along with Rizobium inoculants increases nodulation and Nitrogen fixation in legumes crops. Although legumes fix the nitrogen from the atmosphere but there is evident that application of nitrogenous fertilizers become helpful in increasing the yield [5]. The management of fertilizers is an important factor that affects the yield and yield components of mungbean [6] reported improved mungbean yield with application of major nutrients i.e. NPK.

Keeping in view the importance of nitrogen and phosphorus application for higher productivity of mungbean, the present study was initiated to find out best $\mathrm{N}+\mathrm{P}_{2} \mathrm{O}_{5}$ level to be combined for enhancing yield and yield components of mungbean in agro ecological condition of Mardan.

\section{Materials and Methods}

A field experiment entitled "The combine effect of nitrogen and phosphorus on mungbean yield and yield components" was conducted at "Palato farm of Amir Muhammad Khan Campus Mardan" during summer 2012. The experiment was consisted of different $\mathrm{N}-\mathrm{P}_{2} \mathrm{O}_{5}$ combinations $20+30,40+60,60+90$ and $80+120 \mathrm{~kg} \mathrm{ha}^{-1}$ and a control plot in each replication. The test crop mungbean cultivar NM-92 was sown on $6^{\text {th }}$ April 2012. The experiment was conducted in RCB design with three replications. The plot size was $1.5 \mathrm{~m}$ by $2 \mathrm{~m}$ having 5 rows $1.5 \mathrm{~m}$ long and $30 \mathrm{~cm}$ apart. Plant to plant distance was $10 \mathrm{~cm}$. Urea and DAP were used as source of $\mathrm{N}$ and $\mathrm{P}_{2} \mathrm{O}_{5}$ respectively. The whole fertilizers were applied at sowing time. For seedbed preparation, ploughing was done followed by planking. The crop was irrigated according to need. Weeding and hoeing was done when needed.
Data on days to emergence was recorded visually when $75 \%$ plants emerged in each plot and were counted from the date of sowing. Days to flowering data was recorded by counting number of days from date of sowing till $75 \%$ of flower initiate in each plot. Data on days to maturity was recorded when $75 \%$ pods loss its green color and become black. Plant height data was recorded by measuring height of 10 plants from base to tip, which were selected randomly from each plot. Pods per plant data was recorded by counting number of pods from 5 plants selected randomly from each plot. Data on seed per pod was determined by counting seeds in 10 pods selected randomly from each plot. Data was obtained by counting and weighing 1000 seed selected from grain lot of each plot. Total grain yield data was determined by taking weight of whole seed obtained from each plot after harvesting and threshing 4 central rows. Data on biological yield was recorded by weighing the harvesting four central rows in each plot and were kept in field for sun drying. Harvest index was obtained by dividing grain yield on biological yield and multiplied by 100 . The data was analyzed in randomized complete block design (RCBD) according to [7]. The treatment means were compared at 5\% level of probability using LSD test.

\section{Results}

\section{Days to emergence}

Statistical analysis of days to emergence data shows that control vs rest remains nonsignificant. Different levels of nitrogen and phosphorus showed non-significant effect on days to emergence (Table 1).

\section{Days to flowering}

The data regarding days to flowering present in (Table 1) shows that control vs. rest was non-significant. Maximum days to flowering were taken when $\mathrm{N}+\mathrm{P}_{2} \mathrm{O}_{5}$ applied at the rate of $40+60 \mathrm{~kg} \mathrm{ha}^{-1}$ (40 days) while minimum of days (37) were taken when $\mathrm{N}+\mathrm{P}_{2} \mathrm{O}_{5}$ 
applied at the rate of $60+90 \mathrm{~kg} \mathrm{ha}^{-1}$ and $80+120 \mathrm{~kg} \mathrm{ha}^{-1}$.

\section{Days to maturity}

The data on days to maturity presented in (Table 1) shows that the effect of $\mathrm{N}+\mathrm{P}_{2} \mathrm{O}_{5}$ on days to maturity was significant. More days were taken by control (60) as compare to rest of the plots (53) while in treated plots when $\mathrm{N}+\mathrm{P}_{2} \mathrm{O}_{5}$ applied $40+60 \mathrm{~kg}$ and $60+90$ $\mathrm{kg} \mathrm{ha}^{-1}$ (54 days) took more days than that plot when $\mathrm{N}+\mathrm{P}_{2} \mathrm{O}_{5}$ applied $20+30 \mathrm{~kg}$ (53 days) and $80+120 \mathrm{~kg} \mathrm{ha}^{-1}$ (52 days) to become mature.

\section{Plant height (cm)}

It is evident from the data presented in (Table 1) that the effect of $\mathrm{N}+\mathrm{P}_{2} \mathrm{O}_{5}$ on plant height was significant. Minimum plant height was recorded in control $(40.26 \mathrm{~cm})$ as compare to the rest $(52.81 \mathrm{~cm})$. While in treated plots maximum plant height was recorded when $\mathrm{N}+\mathrm{P}_{2} \mathrm{O}_{5}$ applied at the rate of $40+60 \mathrm{~kg} \mathrm{ha}^{-1}(54.22 \mathrm{~cm})$ and minimum plant height with application of $20+30 \mathrm{~kg}$ $\mathrm{N}+\mathrm{P}_{2} \mathrm{O}_{5} \mathrm{ha}^{-1}(51.30 \mathrm{~cm})$.

\section{Pods plant ${ }^{-1}$}

Data regarding Pods plant ${ }^{-1}$ presented in (Table 1) shows that the control vs. rest was highly significant. Maximum number of pods per plant was obtained with treated (15) as compare to control (12). While among the treated maximum number of pods were obtained by the plot to which $40+60 \mathrm{~kg}$ $\mathrm{ha}^{-1} \mathrm{~N}+\mathrm{P}_{2} \mathrm{O}_{5}$ was applied (17) and minimum number of pods were obtained with the application of $20+30$ and $80+120 \mathrm{~kg}$ $\mathrm{N}+\mathrm{P}_{2} \mathrm{O}_{5} \quad \mathrm{ha}^{-1}$

(14).

Table 1. The combine effect of nitrogen \& phosphorus on mungbean phenology, plant height and pods plant $^{-1}$.

\begin{tabular}{llllll}
$\begin{array}{l}\text { Treatments } \\
\mathbf{N}+\mathbf{P}_{\mathbf{2}} \mathbf{O}_{\mathbf{5}} \\
\left.\mathbf{( k g ~ h a}^{-1}\right)\end{array}$ & $\begin{array}{l}\text { days to } \\
\text { emergence }\end{array}$ & $\begin{array}{c}\text { days to } \\
\text { flowering }\end{array}$ & $\begin{array}{l}\text { days to } \\
\text { maturity }\end{array}$ & $\begin{array}{l}\text { plant } \\
\text { height }\end{array}$ & $\begin{array}{l}\text { pods } \\
\text { plant }^{-1}\end{array}$ \\
\hline $20-30$ & 5.00 & 39 & $53 \mathrm{~b}$ & $51.30 \mathrm{a}$ & $14 \mathrm{bc}$ \\
$40-60$ & 4.67 & 40 & $54 \mathrm{~b}$ & $52.66 \mathrm{a}$ & $17 \mathrm{a}$ \\
$60-90$ & 5.00 & 37 & $54 \mathrm{~b}$ & $54.22 \mathrm{a}$ & $15 \mathrm{ab}$ \\
$80-12$ & 5.00 & 37 & $52 \mathrm{~b}$ & $53.06 \mathrm{a}$ & $14 \mathrm{bc}$ \\
\hline LSD & $\mathrm{ns}$ & $\mathrm{ns}$ & 2.63 & 5.71 & 2.5 \\
\hline Control vs Rest & & & & & \\
Control & 5.33 & 39 & $60 \mathrm{a}$ & $40.26 \mathrm{~b}$ & $12 \mathrm{c}$ \\
Rest & 4.92 & 38 & $53 \mathrm{~b}$ & $52.81 \mathrm{a}$ & $15 \mathrm{ab}$ \\
\hline
\end{tabular}

\section{Seeds pod ${ }^{-1}$}

Data regarding seeds per pod are presented in (Table 2) shows that there was significant difference in the number of seed per pod between controls vs. rest. From control plot (9) number of seed per pod was obtained as compare to treated (11). Among the treated maximum number of seed per pod were obtained with application of $40+60 \mathrm{~kg} \mathrm{ha}^{-1}$ $\mathrm{N}+\mathrm{P}_{2} \mathrm{O}_{5}$ (12) whereas minimum seed per pod were obtained from the plot with $\mathrm{N}+\mathrm{P}_{2} \mathrm{O}_{5}$ application at the rate of $20+30 \mathrm{~kg}$ $\mathrm{ha}^{-1}(10)$.

\section{Thousand grain weight (g)}

Data regarding thousand-grain weight are presented in (Table 2) shows that the control vs. rest was significant. The lower thousandgrain weight (38.27 gm) was obtained from control plot as compare to average of treated plots (52.34 gm). Among the treated plots high grain weight was obtained by application of $\mathrm{N}+\mathrm{P}_{2} \mathrm{O}_{5}$ at the rate of $20+30$ $\mathrm{kg} \mathrm{ha}$ (56.06 $\mathrm{gm})$ and minimum was obtained from application of $40+60 \mathrm{~kg} \mathrm{ha}^{-1}$ $\mathrm{N}+\mathrm{P}_{2} \mathrm{O}_{5}(50.52 \mathrm{gm})$.

Grain yield (kg ha-1)

Data regarding grain yield $\left(\mathrm{kg} \mathrm{ha} \mathrm{ha}^{-1}\right)$ are reported in (Table 2). Significant variation 
was observed in grain yield between control and rest. Highest grin yield (2863 kg ha-1) was obtained with treated as compare to (1780 kg ha-1) from control. Highest grain yield was obtained with $40+60 \mathrm{~kg} \mathrm{ha}{ }^{-1}$ $\mathrm{N}+\mathrm{P}_{2} \mathrm{O}_{5}$ application (3275 $\mathrm{kg} \mathrm{ha}^{-1}$ ) while lowest grain yield was $\left(2653 \mathrm{~kg} \mathrm{ha}^{-1}\right)$ obtained with $80+120 \mathrm{~kg} \mathrm{ha}^{-1} \mathrm{~N}+\mathrm{P}_{2} \mathrm{O}_{5}$ application.

\section{Biological yield ( $\mathrm{kg} \mathrm{ha}^{-1}$ )}

The biological yield data are shown that there is a significant difference among the different treatments (Table 2). Data indicates that control produced lower biological yield $\left(6070 \mathrm{~kg} \mathrm{ha}^{-1}\right)$ then the rest $\left(8922 \mathrm{~kg} \mathrm{ha}^{-1}\right)$. Among the treated the highest biological yield was obtained with application of $\mathrm{N}+\mathrm{P}_{2} \mathrm{O}_{5}$ at the rate of $60-90 \mathrm{~kg} \mathrm{~N}+\mathrm{P}_{2} \mathrm{O}_{5} \mathrm{ha}^{-1}$ $\left(9567 \mathrm{~kg} \mathrm{ha}^{-1}\right)$ and lowest was obtained with $40+60 \mathrm{~kg} \mathrm{ha}^{-1} \mathrm{~N}+\mathrm{P}_{2} \mathrm{O}_{5}$ application $(8580 \mathrm{~kg}$ $\left.\mathrm{ha}^{-1}\right)$.

\section{Harvest index}

Harvest index data presented in (Table 2) shows that treated vs. control were significantly. The preplanned comparison indicates that control had lower harvest index (29.3\%) than the rest $(32.08 \%)$. Among the treated plots highest harvest index were obtained with $40+60 \mathrm{~kg} \mathrm{ha}^{-1}$ $\mathrm{N}+\mathrm{P}_{2} \mathrm{O}_{5}$ and the lowest harvest index was obtained with $20+30 \mathrm{~kg} \mathrm{ha}^{-1}$ of $\mathrm{N}+\mathrm{P}_{2} \mathrm{O}_{5}$.

Table 2.The combine effect of nitrogen $\&$ phosphorus on mungbean yield and yield components.

\begin{tabular}{|c|c|c|c|c|c|}
\hline $\begin{array}{l}\text { Treatments } \\
\mathbf{N}_{+} \mathbf{P}_{2} \mathbf{O}_{5} \\
\left(\mathbf{k g ~ h a}^{-1}\right)\end{array}$ & $\begin{array}{l}\text { seed } \\
\operatorname{pod}^{-1}\end{array}$ & $\underset{(\mathrm{g})}{\mathbf{T G W}}$ & $\begin{array}{l}\text { grain } \\
\text { yield }\end{array}$ & $\begin{array}{l}\text { biological } \\
\text { yield }\left(\mathrm{kg} \mathrm{ha}^{-1}\right)\end{array}$ & $\begin{array}{l}\text { harvest } \\
\text { index }(\%)\end{array}$ \\
\hline $20-30$ & $10.00 \mathrm{~cd}$ & $56.06 \mathrm{a}$ & $2840 \mathrm{~b}$ & $8897 \mathrm{ab}$ & $31.9 \mathrm{~b}$ \\
\hline $40-60$ & $11.67 \mathrm{a}$ & $50.52 \mathrm{a}$ & $3275 \mathrm{a}$ & $8580 \mathrm{~b}$ & $38.2 \mathrm{~b}$ \\
\hline $60-90$ & $11.33 \mathrm{ab}$ & $51.34 \mathrm{a}$ & $2682 \mathrm{~b}$ & $9567 \mathrm{a}$ & $28.0 \mathrm{~b}$ \\
\hline $80-12$ & $10.33 \mathrm{bc}$ & $51.43 \mathrm{a}$ & $2653 \mathrm{~b}$ & $8643 \mathrm{ab}$ & $30.7 \mathrm{~b}$ \\
\hline LSD & 1.23 & 8.06 & 212.7 & 977.5 & 4.6 \\
\hline \multicolumn{6}{|l|}{ Control vs Rest } \\
\hline Control & $9.00 \mathrm{~d}$ & $38.27 \mathrm{~b}$ & $1780 \mathrm{c}$ & $6070 \mathrm{c}$ & $29.3 \mathrm{~b}$ \\
\hline Rest & $10.83 \mathrm{a}$ & $52.34 \mathrm{a}$ & $2863 \mathrm{a}$ & $8922 \mathrm{ab}$ & $32.1 \mathrm{a}$ \\
\hline
\end{tabular}

\section{Discussion}

Nitrogen is an essential nutrient for plant growth and it is the part of every living cell. Phosphorus is also essential nutrient for plant development, which stimulate blooming and seed formation [8]. The partial role of phosphorus is to enhance nitrogen absorption influencing pods and seed formation in legumes and contributing significantly in plant energy processes [9]. Days to emergence were not affected by any treatment it might be due to the short time period of emergence taken by crop or might be attributed to genetically controlling factor. Days to flowering show a decreasing trend with increase in $\mathrm{N}+\mathrm{P}_{2} \mathrm{O}_{5}$ levels.
Similar results were found by [8] that $\mathrm{P}$ enhances flowering.

Days to maturity decreased with increasing in fertilizer levels. The possible reason might be the early flowering and rapid increase in temperature during May and June. The researchers stated that maturity of a crop depends upon photoperiod of genotypes/cultivars, temperatures and slightly on available moisture contents of the plants. Researchers also explained that, days to maturity are a varietal dependent attribute, which influenced by genetic makeup of a cultivars and its environment. Plant height, though being genetically 
controlled character, it increased with increasing level $\mathrm{N}+\mathrm{P}_{2} \mathrm{O}_{5}$ fertilizer, the same finding were observed that plant height increased with application of inorganic source of $\mathrm{P}_{2} \mathrm{O}_{5}$ by [10] stated that it plant height is significantly influenced by $\mathrm{N}+\mathrm{P}_{2} \mathrm{O}_{5}$ fertilizer.

Pods per plant are an important yielddetermining factor. Pods per plant were increased with application of $\mathrm{N}+\mathrm{P}_{2} \mathrm{O}_{5}$. these results are confirm the findings of [11] reported that nitrogen and phosphorus increase the number of pods per plant of mungbean. Number of seed per pod was increased the $\mathrm{N}+\mathrm{P}_{2} \mathrm{O}_{5}$ application. Similar results observed by [12] who reported increased seed per pod of mungbean with nitrogen and phosphorus application. Thousand-grain weight increased with $\mathrm{N}+\mathrm{P}_{2} \mathrm{O}_{5}$ application. Same results were also found by [13] who stated that application of $\mathrm{P}_{2} \mathrm{O}_{5}$ along with $\mathrm{N}$ application increase thousand-grain weight.

Higher grain yield with increasing application of NP may be attributed to increase in yield components. These results are an agreement with findings of [14] and [15] who also found that grain yield increases with nitrogen and phosphorus application. But [16] reported that a character like seed yield is highly unstable and highly influenced by environment. Increasing level of $\mathrm{N}+\mathrm{P}_{2} \mathrm{O}_{5}$ level up to some extent increased biological yield. Harvest index as affected by varying level of nitrogen and phosphorus application. These results are similar to the findings of [11], who also reported an increase in harvest index of mungbean in response to application of $\mathrm{N}+\mathrm{P}_{2} \mathrm{O}_{5}$.

\section{Conclusion}

It is concluded that different combination of nitrogen and phosphorus are beneficial in order to improve the nutrient utilization efficiency and yield components in agro ecological condition of Mardan.

\section{Authors' contributions}

Conceived and designed the experiments: Anjum, MZ Afridi. Performed the experiments: Anjum, MZ Afridi. Analyzed the data: Anjum, MZ Afridi. Wrote the paper: K Akhtar and VN Ha.

\section{References}

1. MINFAL, (2011). Ministry of food, agriculture and livestocks. Agriculture statistics of pakistan, 2010-2011. Governament of pakistan , Islamabad

2. Malik BA (2011). Grain Legume. In: Crop Production (Eds): E. Bashir and R. Bantel R. National Book Foundation, Islamabad, Pakistan, pp. 277-328.

3. Asaduzzaman M, Chowdhury S, \& Ali MA (2010). Phosphorus and weedinon growth and yield of mungbean. IJBSM. 1(1): 54-58.

4. Bhuiyan, MMH, Rehman MM, Afroze F, Sutradhar GNC, \& Bhuiyan MIS (2008). Effect of phosphorus molybdenum and Rhizobium inoculation on growth and nodulation of mungbean. J Soil Nature. 2(2): 25-30.

5. Ardeshana RB, Modhwadia MM, Khanparal VD \& Patel JC (1993). Response of greengram (Phaseolus radiatus) to nitrogen, phosphorus and Rhizobium inoculation. Indian J Agron, 38(3): 490-492.

6. Singh AK, Chaudhry RK, \& Sharma RPR (1993). Effect of inoculation and fertilizer level on yield, nutrients uptake and economics of summer pulses. Indian J Potassium Res, 9: 176-178.

7. Jan, MT, Shah P, Hollingoton $\mathrm{P}$, Khan MJ \& Sohial Q (2009). Agriculture research design and analysis. Prof. Dr. M. Tariq. Jan. Dept. of agronomy NWFP Agric. University Peshawar. Pakistan.

8. Akhtar M, Ahmad S, Mohsin S \& Mahmood T (1999). Interactive effect of phosphorus and potassium nutrition on the growth and yield of hybrid maize 
(zea mays L). Pakistan J Biol Science 2: 240-241.

9. Anetor MO, \& Akinrinde EA (2006). Differences in the liming potential of some fertilizer materials in a tropical acid alfisol. J Applied Science 6:16861691.

10. Sharma MP \& Room S (1993). Effect of phosphorus and sulphur application on yield and quality of green gram. Indian J Agric. Science 63: 507-508.

11. Ahamd Z \& Ashiq R (1992). Genetic varability and correlation studies in rice bean. Pakistan J Agriculture Research 13: 121-125.

12. Masih I (1998). Determining suitable levels of nitrogen and phosphorus for obtaining maximum yield of mungbean cv. NM-92. M.Sc. (Hons.) Agri.

13. Tariq M, Khaliq A \& Umar M (2001). Effect of phosphorus and potassium application on growth and yield of mungbean. Online. J biol Science 1(6): 427-428.

14. Patel TS \& Pramer MT (1986). Response of green gram to varying levels of nitrogen and phosphorus. Madras Agri J 73:355-356.

15. Taj M (1996). Determining the suitable levels of nitrogen and phosphorus for obtained maximum yield of mungbean cultivar NMN-51. M.Sc. (Hons.) Agri. Thesis, Dept. of Agronomy Univ. Agri. Faisalabad.

16. Norman MZT, Pearson CJ, Searle PGE (1984). The Ecology of Tropical Crops., Colombia, USA 107. 